\title{
The influence of Banks' liquidity in macroeconomy
}

\author{
Xiaohan Huang ${ }^{1, a}$, Boyao $\mathrm{Li}^{2, \mathrm{a}}$,Weiming Zhang ${ }^{1, \mathrm{a}}$, Peiteng Shi ${ }^{1, \mathrm{a}}$ \\ ${ }^{1}$ Science and Technology on Information Systems Engineering Laboratory, \\ National University of Defense Technology, Changsha 410073,China \\ ${ }^{2}$ School of Systems Science, Beijing Normal University, Beijing 100875, China \\ ahuangxiaohan0125@163.com,
}

Keywords: liquidity, ACE model, macroeconomic variable

\begin{abstract}
This paper builds an economical model, which includes the department of household, enterprise and bank, based on the Agent-Based Computational Economic (ACE) and the Stock-Flow Consistent model (SFC). We choose the short-term liquidity needs LCR as the bank liquidity standard, and investigate how the shock may impact the subject attributes and the change trend of the whole macroeconomic variable in short term. The results can provide theory reference for prediction and prevention of bank liquidity risk, which could promote the development and improvement of the supervision system of bank liquidity.
\end{abstract}

\section{Introduction}

In modern economy, as the finance intermediary, bank has become the main center of economic activities. Its antenna widely penetrates in every corner of economy having a huge impact on society. For example, the sub-prime crisis occurred in 2007 became a global financial storm, bringing enormous impact and destruction to a lot of countries' economy. As a key part of financial marker, the bank system was severely damaged in this crisis. Some big banks have failed for insolvency or depositor runs. While a damaging storm spread in banking around the world for the interbank lending. Interbank lending makes the banking a high-connected cash flow network. In this network, most of banks will be affected once a few important banks collapsed. And cascading effect for illiquidity spread in a feedback loop between cash and futures markets. Briefly, at present, the bank cannot control the risk in a short time effectively, and the interbank contagion is greatly destructive. Hence, it's quite urgent for the researchers to do research on banking liquidity risk management.

In recent years, bank liquidity has become a hot research field with broad application prospects. The earliest study is DD model by Diamnd\&Dybvig. DD model discusses how the lack of bank liquidity leads to huge loss of economy. The paper points out that stable banks can not escape from being bankrupt when bank rum phenomenon happens ${ }^{[1]}$, which shows that the banking system is pretty fragile. At present, there are a wide range of studies on the causes and influence factors of bank liquidity, but scholars seldom investigate the interaction mechanism among various factors ${ }^{[2]}$. In mainstream economics, the role of banks is often neglected. On one hand, reserve fund system and the creating process of money are often isolated from macro economic model, usually considered as exogenous variables when building model ${ }^{[3]}$. On the other hand, in macroeconomic model, banks are not included in the forecast and policy analysis ${ }^{[4-6]}$. In order to have a better understanding on the internal mechanism of bank liquidity, some scientists try to use a variety of methods to consider and discuss the economic process. It is proved that these paradigms and methods are effective in a certain degree. Among them, the Stock Flow Consistency(SFC) model and the multi-agent calculation method ${ }^{[7]}$ provide a well explanation to real economy operation ,and are widely approved by scholars.

This paper builds an economical model, which is consisting of three departments: household, enterprise and bank. We choose the short-term liquidity needs liquidity cover rate(LCR) as the standard of bank liquidity, investigate how the shock impacts the subject attribute and the change trend of the whole macroeconomic variable in the short term. The results can provide theory 
reference for bank liquidity risk prediction and prevention, which could promote the development and improvement of the supervision system of bank liquidity.

\section{Methods}

There is three kinds of agents in the Three-Department model built in this paper: household $(\mathrm{H})$, enterprise (F) and bank. Bank includes commercial bank (B) and central bank. The same agents share common attributes and interactive rules. This paper assumes that the order of three agents quantity is: $\mathrm{H}>\mathrm{F}>\mathrm{B}$. The central bank is in charge of supervising the market and setting the reserve requirements.

Household. Households get their salary from enterprises by working for them, consume according to a certain proportion of income, deposit and withdraw their money from the bank. The balance sheet can be depicted in Table 1.

Table 1 Household balance sheet

\begin{tabular}{|c|c|}
\hline Property & Liabilities \\
\hline Cash & \\
\hline Deposit & \\
\hline & Net worth \\
\hline
\end{tabular}

Thus, the total assets of each household can be written as:

$$
\mathrm{A}_{\mathrm{t}}^{\mathrm{h}}=\mathrm{C} \mathrm{u}_{\mathrm{t}}^{\mathrm{h}}+\mathrm{D}_{\mathrm{t}}^{\mathrm{h}}
$$

In this equation, $t$ stands for the $t^{\text {th }}$ time step, $h$ represents the household attribute, Cu reveals the cash inventory and $\mathrm{D}$ is the volume of deposit.

The salary can be expressed as:

$$
\mathrm{W}_{\mathrm{t}}=\lambda \mathrm{Y}_{\mathrm{t}}, \lambda \in(0,1)
$$

$\mathrm{Y}$ is the receipts of enterprise during the $\mathrm{t}^{\text {th }}$ time step and $\lambda$ represents the proportion of salary given to households.

The expected consumption function is:

$$
\mathrm{C}_{\mathrm{t}}^{\mathrm{p}}=\alpha_{1} \mathrm{~W}_{\mathrm{t}}+\alpha_{2}\left(\mathrm{D}_{\mathrm{t}}^{\mathrm{h}}+\mathrm{Cu}_{\mathrm{t}}^{\mathrm{h}}\right)
$$

$\mathrm{W}$ is the salary of household, $\alpha_{1}, \alpha_{2}$ stands for household's marginal propensity of consume to salary and surplus wealth respectively.

To simplify household's deposit actions, this paper supposes that the deposit ratio of each household is $\beta$, then the cash inventory $\mathrm{Cu}$ and deposit volume $\mathrm{D}$ can be written as:

$$
\begin{gathered}
\mathrm{Cu}^{\mathrm{h}}=(1-\beta) \mathrm{A}^{\mathrm{h}} \\
\mathrm{D}^{\mathrm{h}}=\beta \mathrm{A}^{\mathrm{h}}
\end{gathered}
$$

Hence, in order to make sure that the deposit ratio is stable, the variation of deposit can be calculated as:

$$
S=\beta A^{h}-D^{h}
$$

Enterprise.Enterprises will analysis the demand of market, hire workers to produce products, and launch products on the market to gain profits, then, conduct the next round of investment according to the profits they get. If enterprise is lack of money, they will take a bank loan and repay a certain proportion in each time cycle. The balance sheet of enterprise is shown in table 2.

Table 2. Enterprise balance sheet

\begin{tabular}{|c|c|}
\hline Property & Liability \\
\hline Cash & Loan \\
\hline & Net worth \\
\hline
\end{tabular}

The enterprise production function can be expresses as:

$$
F(K, N)=A K^{\alpha} N^{\beta}
$$

A is the proportion parameter, $\mathrm{K}$ is capital, $\mathrm{N}$ is labor force, $\alpha$ and $\beta$ stands for the relative 
materiality of capital and labor in production respectively. This paper assumes that $\alpha=0, \beta=1$, namely the enterprise production function is proportional to the number of labors.

When there is still remaining loan, the enterprise should repay $D_{t}$ in one cycle, which is shown in below:

$$
\mathrm{DR}_{\mathrm{t}}=\mathrm{L}_{\mathrm{t}}^{\mathrm{f}} / \rho
$$

$t$ stands for the $t^{\text {th }}$ time step, $f$ represents the enterprise attribute, $L$ is the remaining loan and $\rho$ is repayment ratio.

Then, the net worth can be calculated as:

$$
\Pi_{\mathrm{t}}=\mathrm{Y}_{\mathrm{t}}-\mathrm{W}_{\mathrm{t}}-\mathrm{DR}_{\mathrm{t}}
$$

Supposing that the investment of enterprises is more than their profits, the part in excess of profits is represented by CC, then we can get the investment:

$$
\begin{gathered}
\operatorname{Inv}_{\mathrm{t}}^{\mathrm{d}}=\mathrm{CC}_{\mathrm{t}}^{\mathrm{d}}+\Pi_{\mathrm{t}} \\
\mathrm{CC}_{\mathrm{t}}^{\mathrm{d}}=\eta \mathrm{Y}_{\mathrm{t}}
\end{gathered}
$$

$\mathrm{d}$ is the expected value, $\eta$ reveals the proportion of excess loan to income.

Bank. Bank is mainly in charge of handling the household's deposit or withdrawal business, and the enterprise's debt business. Each bank needs to set aside required statutory reserve according to the regulations, and, specified amount of liquid buffer fund according to Basel III. Then, the bank can do lending and interbank lending in accordance with the amount of loanable money. At the same time, the bank must satisfy the household's deposit withdrawals demand. Its balance sheet is illustrated in table 3.

Table 3 Bank balance sheet

\begin{tabular}{|c|c|}
\hline Property & Liabilities \\
\cline { 1 - 1 } Excess reserves & Deposit \\
\hline Loan & \multirow{2}{*}{$\begin{array}{c}\text { Interbank } \\
\text { lending }\end{array}$} \\
\cline { 1 - 1 } Liquid cushion of funds & Net worth \\
\hline
\end{tabular}

According to Basel III:

buf=Excess reserves + Liquid cushion of funds + Legal reserve

Therefore, the loanable funds can be calculated as:

$$
\mathrm{LF}_{\mathrm{t}}^{\mathrm{b}}=(1-\mathrm{r}) \mathrm{D}_{\mathrm{t}}^{\mathrm{b}}-\mathrm{L}_{\mathrm{t}}^{\mathrm{b}}-\mathrm{buf}_{\mathrm{t}}
$$

$t$ stands for the $t^{\text {th }}$ time step, $b$ represents the bank attribute, $r$ is the legal reserve and $L$ depicts the total amount of remaining loans.

The relationships among three kinds of agents are shown in Figure1. In households and enterprises, each individual is independent and no interaction exists among them, but the banks are connected with each other by the interbank lending. 


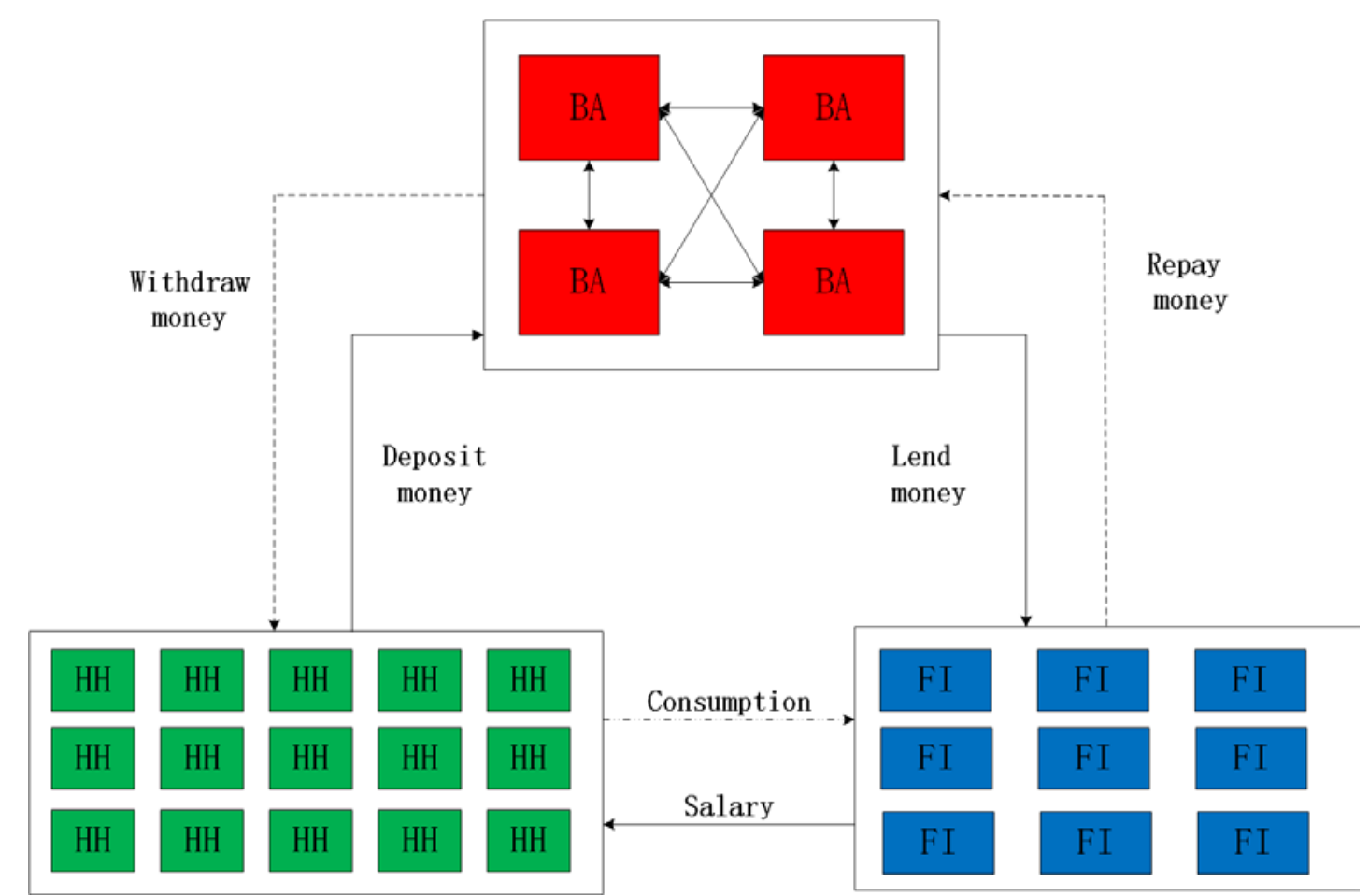

Figure1. The relationships among households, enterprises and banks

\section{Results}

This section shows the simulation results. We simulate the impact of the real economy by setting different parameters. Now, we study the dynamic evolution process of main macro economic quantity with shock acting on bank reserves individually. In addition, shocks are only given exogenously when $\mathrm{T}=100$.

The value of Bank liquidity buffer funds target parameter, ksi changes from 1 to 5.6 when $\mathrm{T}=100$, in order to increase bank liquidity reserves. The results are shown as follows:

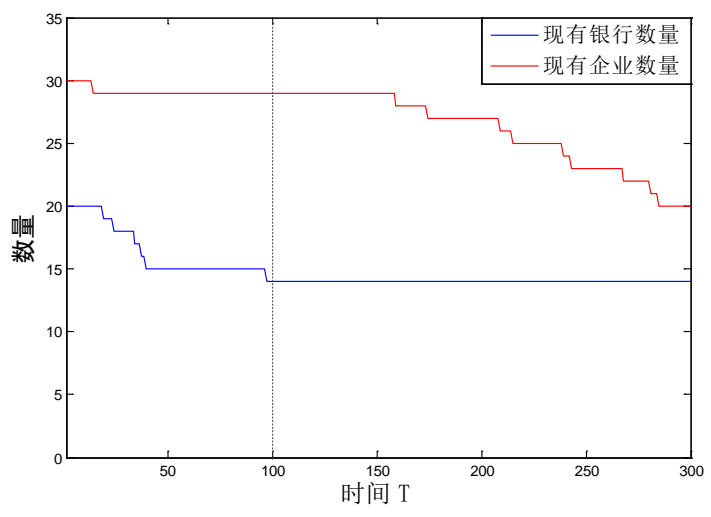

Figure2. Number of existing bank and enterprise

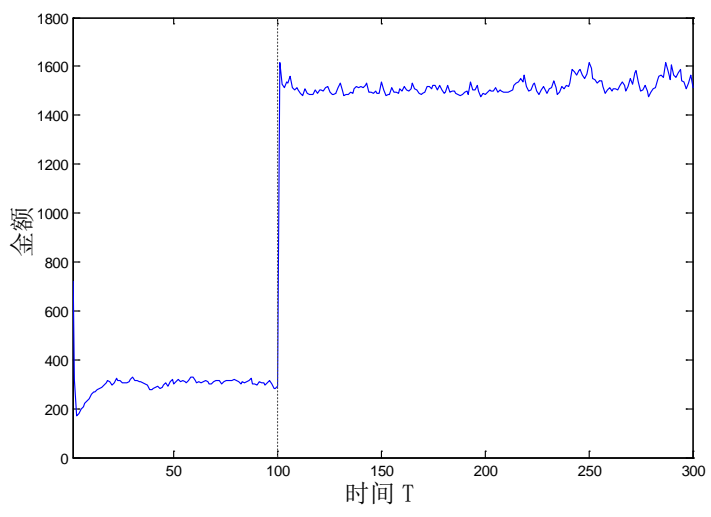

Figure3. Total bank liquidity buffer 


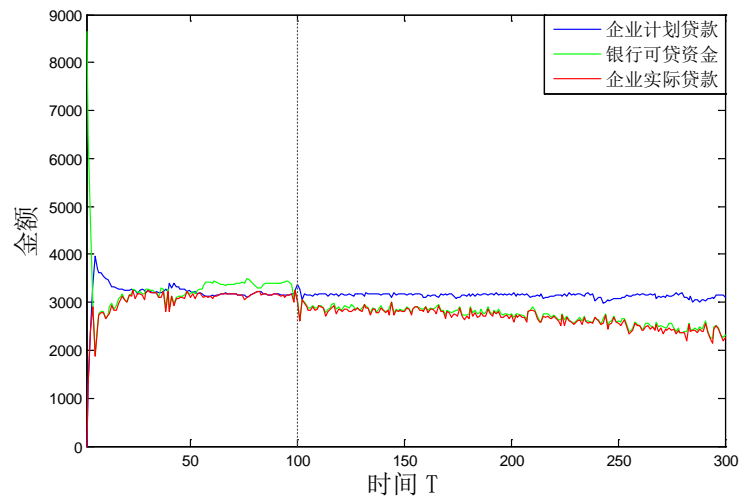

Figure4. Enterprise loans \& Bank loanable funds

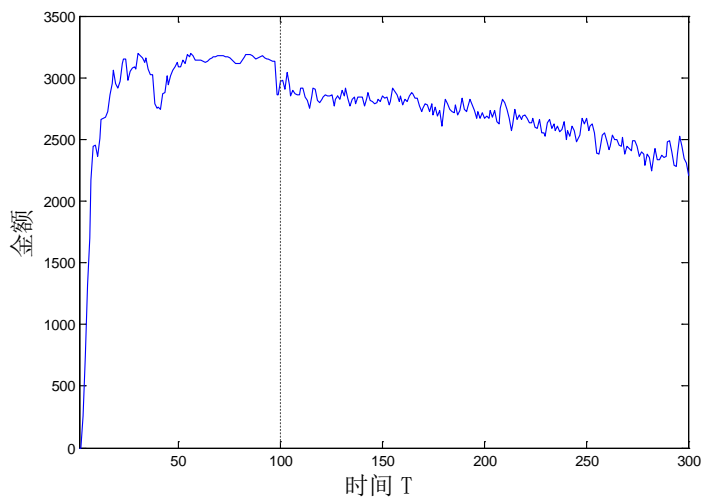

Figure5. Total amount of enterprise loan repayments

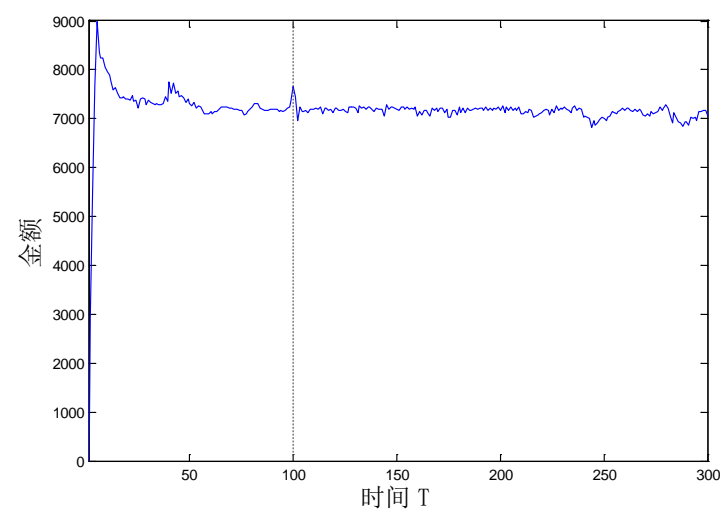

Figure6. GDP

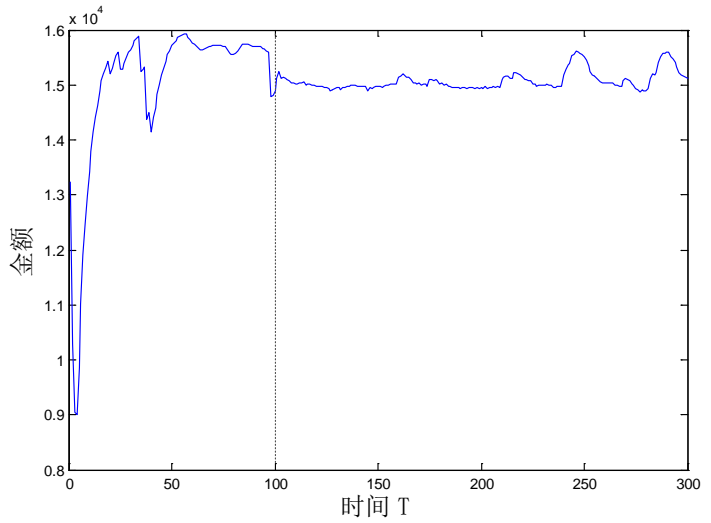

Figure7. M2 (include cash and

deposit）

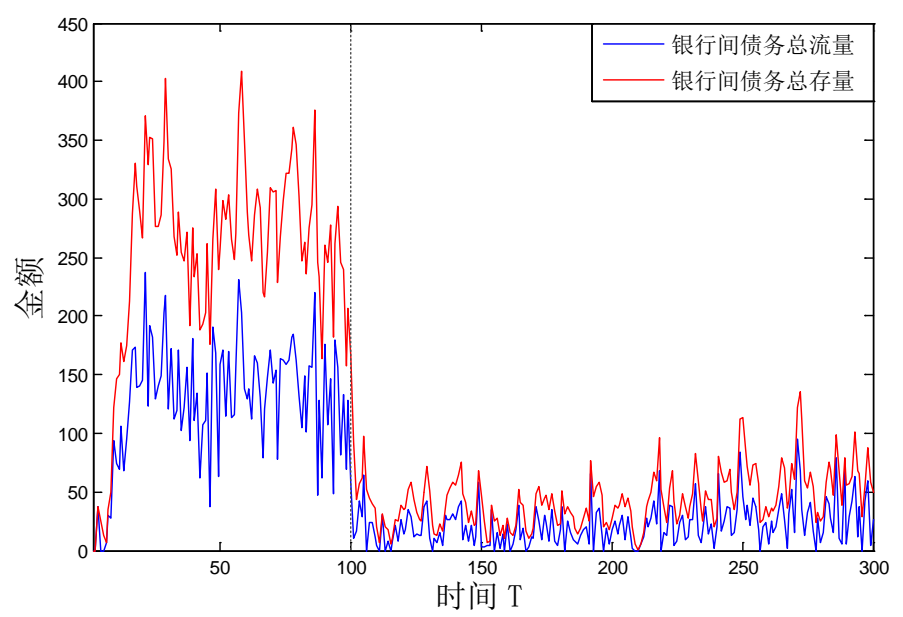

Figure8. Total flow \& Total stock of interbank lending debt

Figure2 demonstrates that the number of survival bank will stay stable in a short term after a given shock, while the amount of enterprise reduces gradually. The shock reduces the loan funds directly in order to increase bank liquidity reserves in Figure3. It makes the entire economic downturn and enterprise is collapsed for the inability to repay maturing loans in Figure4 and Figure5. At the same time, Figure6 and Figure7 depicts that GDP is declining, new loans reduce, M2 reduces and corporate repayment capacity decreases. Also, interbank lending reduces significantly because its liquidity reserves increase in Figure8. The results show serious effects of shock on the macro economy when banks reserve liquidity excessively to protect themselves. We can also see that bank system is endangering for the reduction of bank profits when macro economic declines. 


\section{Summary}

In this paper, we use the multi-agent simulation method to build a micro economic analysis model based on the consistency of flow-stock. The model considers three types of agents: household, enterprise and bank. Each agent is determined by the simplified behavior equation and the interactive rules are determined by capital flow and debt flow. From the simulation results, we find that bank liquidity has a significant impact on macroeconomic. When the bank increase liquidity reserves to protect themselves, economic recession and turns to a vicious spiral. At the same time, the interbank lending makes the whole bank system entangled. It is easy to trigger the system risk, thus affecting entire bank system in some extreme cases. So, do not excess eregulation to bank, otherwise it will make a large number of triangular debt system resulting in unnecessary friction which in not conducive to the stability of bank system.

Through the simulation, we found the change of macroeconomic is consisting of classical economics analysis. It's rationality providing a new perspective to us. Of course, this needs further research and discussion.

\section{Reference}

[1] Diamond D W, Dybvig P H. Bank runs, deposit insurance, and liquidity[J]. The journal of political economy, 1983: 401-419.

[2] Ba X.S.,Yuan P.,Ren J. Review on liquidity management of commercial banks[J]. Finanical Accounting, 2008 (1): 27-33.

[3] Hilton H C. Money Creation, Banks and Macroeconomic Instability[M]. Griffith University, 2008.

[4] Harrison R, Nikolov K, Quinn M, et al. The Bank of England quarterly model[M]. London: Bank of England, 2005.

[5] Dieppe A, González Pandiella A, Willman A. The ECB's New Multi-Country Model for the euro area: NMCM-Simulated with rational expectations[J]. Economic Modelling, 2012, 29(6): 2597-2614.

[6] Bernardo G, Campiglio E. A simple model of income, aggregate demand and the process of credit creation by private banks[J]. Empirica, 2013: 1-25.

[7] Lengnick M, Krug S, Wohltmann H W. Money creation and financial instability: An agent-based credit network approach[J]. Economics: The Open-Access, Open-Assessment E-Journal, 2013, 7(2013-32): 1-44. 